УДК 629.5.01

DOI 10.47049/2226-1893-2020-1-29-54

\title{
ВЛИЯНИЕ РАБОТ \\ ПО ПЕРЕОБОРУДОВАНИЮ КРУИЗНЫХ ПАССАЖИРСКИХ СУДОВ НА ФОРМИРОВАНИЕ ПОМЕЩЕНИЙ ДЛЯ ПАССАЖИРОВ И ЭКИПАЖА
}

\author{
А.Г. Егоров \\ к.т.н., ст. научн. сотрудник \\ Морское инженерное бюро, Украина, Одесса
}

Аннотация. Несмотря на увеличение количества модернизаций, еще не все работающие речные круизные пассажирские суда (РКПС) приведены под современные понятия круиза. Поэтому при разработке проектов модернизаиии, да и новых РКПС, крайне важно иметь представление о реальной ситуации с пассажирскими каютами и общественными помещениями.

Любая модернизация или конверсия РКПС, при условии отсутствия проблем с техническим состоянием судна, проводится с иелью повышения комфортабельности. На таких судах повышение комфортабельности и приведение к современным стандартам обслуживания достигается за счет уменьшения пассажсировместимости, в отличие от морских круизных пассажирских судов и лайнеров, для которых, в больиинстве своем, возможно изменение габаритных размерений.

При этом также меняются распределение площадей и компоновка помещений. Увеличивается удельная площадь кают с 2,0-4,5 м²/чел до 9,0-12,0 м²/чел, удельная площадь общественных помещений $c$ 4,5-9,0 м²/чел до 11,5-16,0 м²/чел. Увеличивается также количество экипажа и обслуживающего персонала на одного пассажира до 0,51, что повышает уровень обслуживания на борту.

В качестве объектов для исследования выбраны наиболее подходящие для модернизаиий суда из первой (суда проектов 785, 26-37, 588, $305,646,860)$ и второй (проекты 301, 302, Q-040, Q-056, Q-065, 92-016) групп РКПС.

Зависимости, полученные при выполнении работы, позволят упростить прочесс проектирования на начальных стадиях проектирования, в том числе, при выполнении проектных работ по модернизации и конверсии РКПС.

Ключевые слова: речное круизное пассажирское судно, комфортабельность, модернизачия, конверсия, анализ, площадь, закономерность.

(C) Егоров А.Г., 2020 
ВІСНИК

ОДЕСЬКОГО НАЦІОНАЛЬНОГО

МОРСЬКОГО УНІВЕРСИТЕТУ
HERALD

OF THE ODESSA NATIONAL

MARITIME UNIVERSITY

№ 1 (61), 2020

УДК 629.5.01

DOI 10.47049/2226-1893-2020-1-29-54

\title{
ВПЛИВ РОБІТ \\ З ПЕРЕОБЛАДНАННЯ КРУЇЗНИХ ПАСАЖИРСЬКИХ СУДЕН НА ФОРМУВАННЯ ПРИМШЩЕНЬ ДЛЯ ПАСАЖИРІВ І ЕКІПАЖУ
}

\author{
О.Г. Сгоров \\ к.т.н., ст. наук. співпрацівник \\ Морське інженерне бюро, Україна, Одеса
}

Анотація. Незважаючи на збільшення кількості модернізацій, ще не всі прачюючі річкові круїзні пасажирські судна (РКПС) приведені під сучасні поняття круїзу. Тому при розробиі проектів модернізації, та й нових РКПС, вкрай важллво мати уявлення про реальну ситуацію 3 пасажирськими каютами і загальними приміщеннями.

Будь-яка модернізаиія або конверсія РКПС, за умови відсутності проблем з технічним станом судна, проводиться з метою підвищення комфортабельності. На таких суднах підвищення комфортабельності і приведення до сучасних стандартів обслуговування досягається за рахунок зменшення пасажиромісткості, на відміну від морських круїзних пасажирських суден і лайнерів, для яких, в більшості своїй, можлива зміна габаритних розмірень.

При иьому також змінюються розподіл площ $і$ компонування приміщень. Збільшусться питома площза кают з 2,0-4,5 $\mathrm{m}^{2}$ чол до 9,0-12,0 $\mathrm{m}^{2}$ чол, питома площза загальних приміщень з 4,5-9,0 $\mathrm{m}^{2} /$ чол до 11,5-16,0 м²/чол. Збільшується також кількість екіпажу та обслуговуючого персоналу на одного пасажира до 0,51, щзо підвищуе рівень обслуговування на борту.

Як об'єкти для дослідження обрані найбільш відповідні для модернізаиій судна з першої (судна проектів 785, 26-37, 588, 305, 646, 860) і другої (проекти 301, 302, Q-040, Q-056, Q-065, 92-016) груп РКПС.

Залежності, отримані при виконанні роботи, дозволять спростити прочес проектування на початкових стадіях проектування, в тому числі, при виконанні проектних робіт з модернізаиії $і$ конверсії РКПС.

Ключові слова: річкове круїзне пасажирське судно, комфортабельність, модернізачія, конверсія, аналіз, площа, закономірність. 
UDC 629.5.01

DOI 10.47049/2226-1893-2020-1-29-54

\title{
INFLUENCE OF MODERNIZATION WORKS OF CRUISE PASSENGER SHIPS ON FORMATION OF COMPARTMENTS FOR PASSENGERS AND CREW
}

\author{
A. Egorov \\ Candidate of Technical Sciences, Senior Researcher \\ Marime Engineering Bureau, Odessa, Ukraine
}

\begin{abstract}
Despite increase in number of modernizations, not all working river cruise passenger ships (RCPS) fitted modern cruise requirements. Therefore, when developing modernization projects and projects of new RCPS, it is extremely important to have information about real situation with passenger cabins and public spaces.

Any RCPS modernization or conversion, if there are no problems with technical conditions of the ship, is carried out in order to increase comfort level. On such ships, increase of comfort level and fit to modern standards of service are achieved by reducing passenger capacity unlike to sea cruise passenger ships and liners, for which foremost changes in overall dimensions are possible.

At the same time distribution of areas and layout of compartments are also subjects to change. Specific area of passenger cabins is increasing from 2,0-4,5 $\mathrm{m}^{2} /$ pas to 9,0-12,0 $\mathrm{m}^{2} / \mathrm{pas}$, the specific area of public compartments from 4,5-9,0 $\mathrm{m}^{2} /$ pas to $11,5-16,0 \mathrm{~m}^{2} /$ pas. Average area of passenger cabin on conversed RCPS of PV06 project in comparison with initial 588 project ship has increased on 196,7\% (from 4,1 $\mathrm{m}^{2}$ to $12,2 \mathrm{~m}^{2}$ ). Average area of passenger cabin on conversed RCPS of PV08 project in comparison with initial Q-065 project ship has increased on 188,2\% (from 7,5 $\mathrm{m}^{2}$ to 21,6 $\mathrm{m}^{2}$ ). Specific area of public compartments on conversed RCPS of PV06 project in comparison with initial 588 project ship has increased on 232,3\% (from $4,7 \mathrm{~m}^{2} /$ pas to $15,7 \mathrm{~m}^{2} /$ pas). Specific area of public compartments on conversed RCPS of $P V 08$ project in comparison with initial Q-065 project ship has increased on $63,0 \%$ (from $9,0 \mathrm{~m}^{2}$ /pas to $14,7 \mathrm{~m}^{2} /$ pas). The number of crew and operational personnel per passenger increases up to 0.51, which increases the level of service on board. Ships of the first (projects 785, 26-37, 588, 305, 646, 860) and the second (projects 301, 302, Q-040, Q-056, Q-065, 92-016) groups of RCPS had been chosen as the most suitable ships for modernization.

Correlations received during the work will simplify the design process of basic projects, including design works on modernization and conversion of $R C P S$.
\end{abstract}

Keywords: river cruise passenger vessel, comfortableness, modernization, conversion, analysis, area, correlation. 
Постановка проблемы. Флот отечественных речных круизных пассажирских судов (РКПС) стареет. Причем, как показывают исследования $[1 ; 2]$, в первую очередь, морально. В крайние годы значительно повысились требования туристов к комфорту на борту, что отразилось на темпах и объемах модернизационных работ. За последние пять лет было модернизировано более 30 отечественных речных круизных пассажирских судов (РКПС), из них 13 - существенно, с повышением уровня комфортабельности [3].

Тенденции на отечественном рынке вполне соответствуют европейскому, где с 2013 года происходит рост числа круизов, прежде всего, за счет американских туристов [4].

Для европейского речного рынка в 2019 году планируется сдать в эксплуатацию 20 новых круизных судов; в 2018 году было сдано 10 РКПС и 3 судна было существенно модернизировано, включая одно переоборудование из грузовой баржи [5].

Несмотря на увеличение количества модернизаций, еще не все работающие РКПС приведены под современные понятия круиза. Поэтому при разработке проектов модернизации, да и новых РКПС, крайне важно иметь представление о реальной ситуации с пассажирскими каютами и общественными помещениями.

Целью статьи является определение закономерностей изменения распределения площадей помещений РКПС в результате модернизаций и конверсий для оценки на начальных стадиях проектирования.

Изложение основного материала. Любая модернизация или конверсия РКПС, при условии отсутствия проблем с техническим состоянием судна, проводится с целью повышения комфортабельности. На таких судах повышение комфортабельности и приведение к современным стандартам обслуживания $[1 ; 6]$ достигается за счет уменьшения пассажировместимости, в отличие от морских круизных пассажирских судов и лайнеров, для которых, в большинстве своем, возможно изменение габаритных размерений (см. рисунок 1) [7; 8]. помещений.

При этом также меняются распределение площадей и компоновка

Автором был выполнен соответствующий анализ изменения распределения площадей палуб (см. таблицы 1-6). В качестве объектов для исследования выбраны наиболее подходящие для модернизаций суда из первой (суда проектов 785, 26-37, 588, 305, 646, 860) и второй (проекты 301, 302, Q-040, Q-056, Q-065, 92-016) групп РКПС [9].

Наглядно изменение площадей и компоновки пассажирских кают представлено на рисунке 2.

Примеры кают на модернизированных и конверсионных РКПС приведены на рисунках 3-5. 


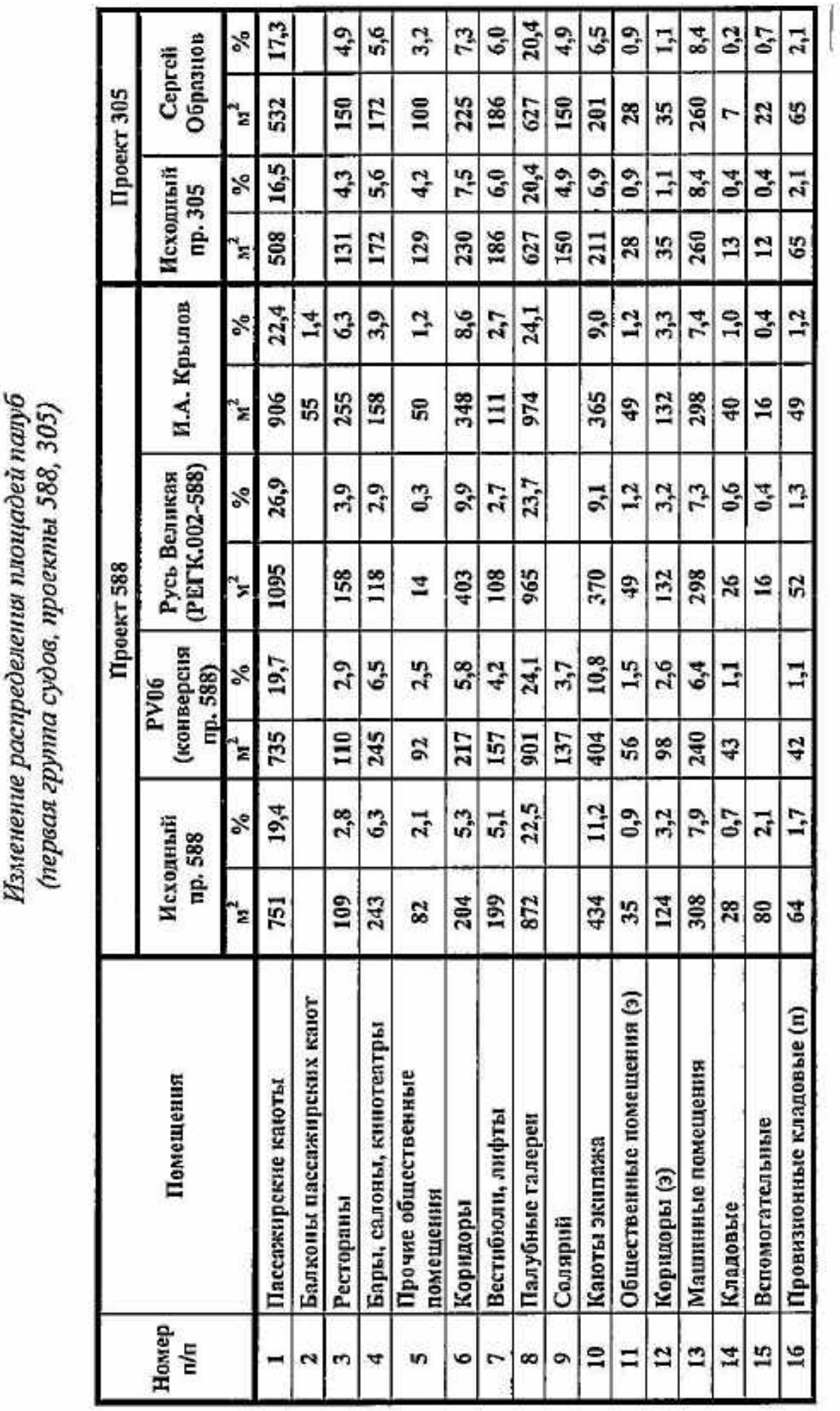


ฐ்ุ

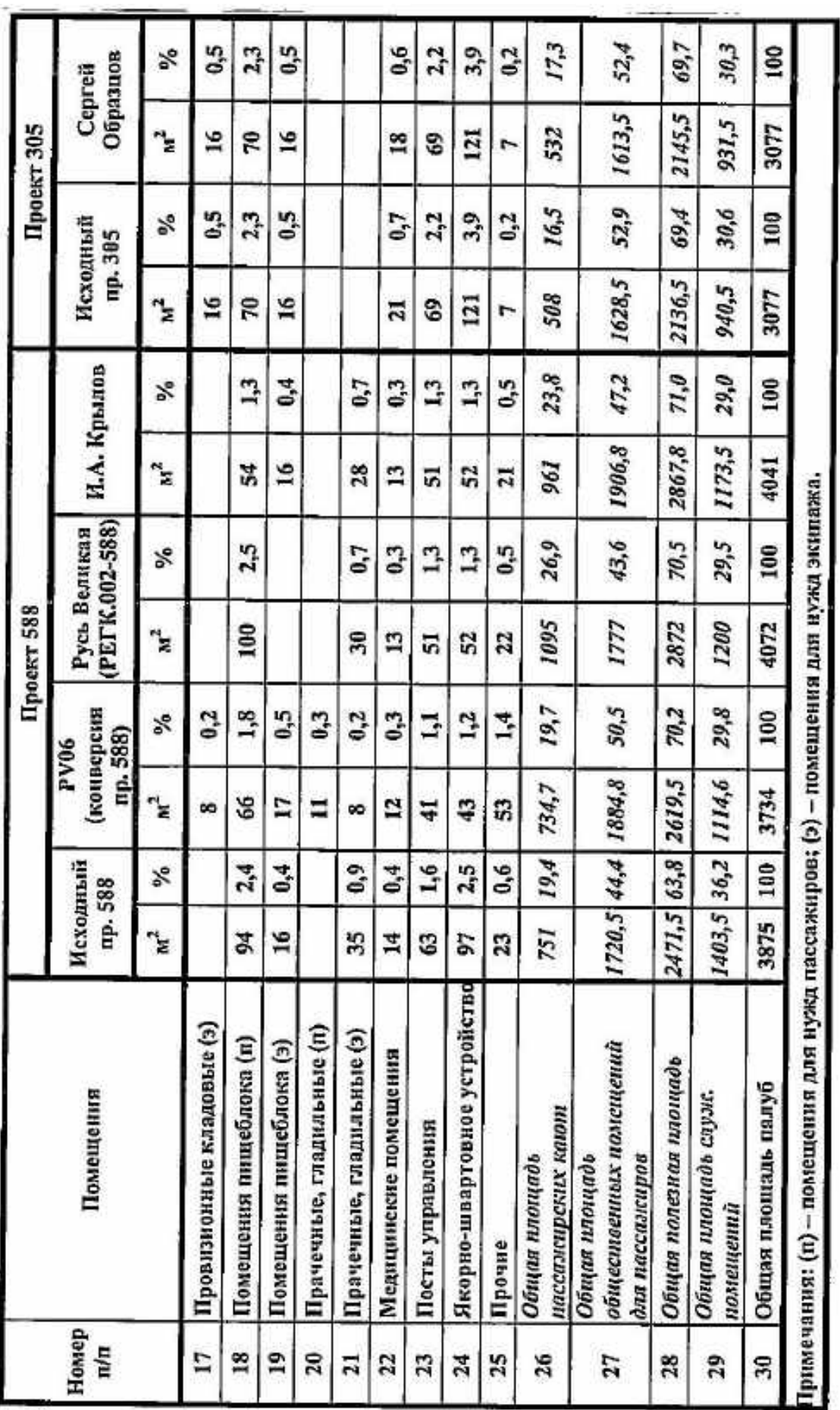


ֻ

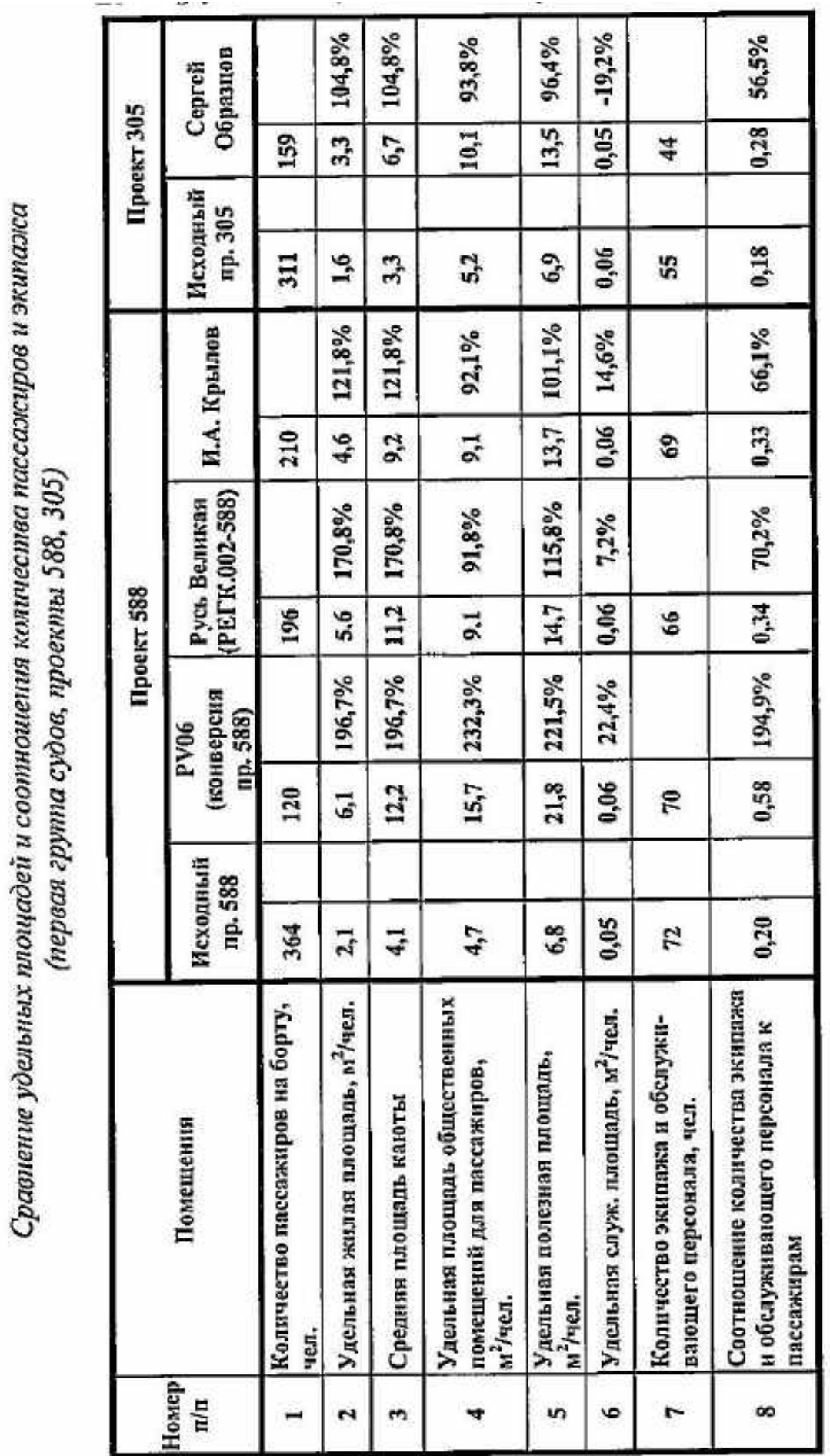




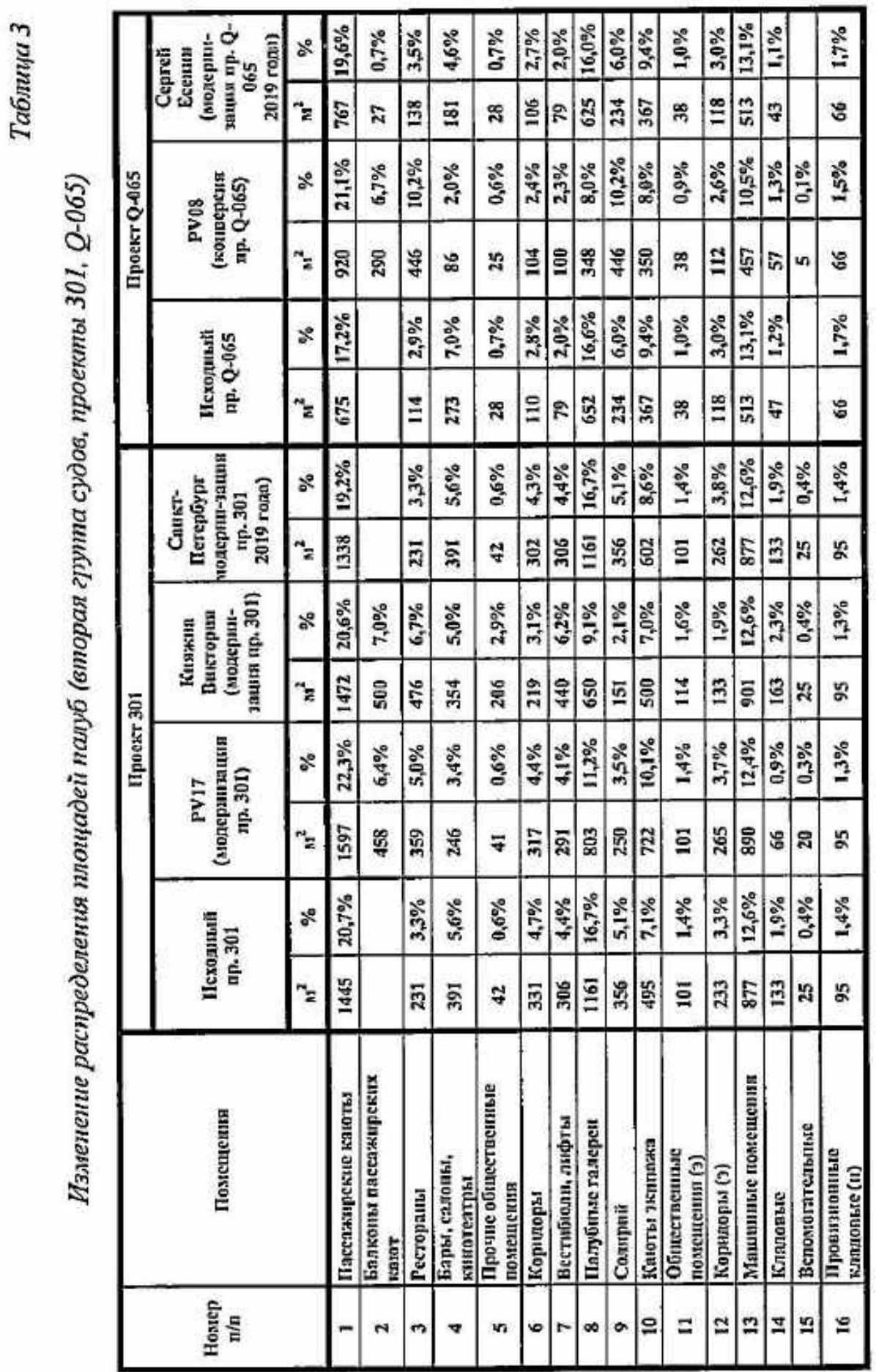




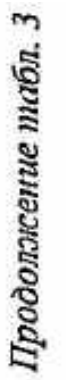

\begin{tabular}{|c|c|c|c|c|c|c|c|c|c|c|c|c|c|c|c|c|}
\hline \multirow{6}{*}{ 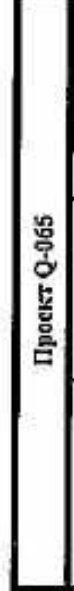 } & \multirow{2}{*}{ 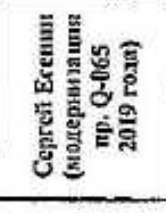 } & $\approx$ & & $\stackrel{\mathrm{m}}{े}^{\mathrm{a}}$ & ণัे & 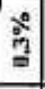 & & 尝 & $\begin{array}{l}3 \\
\text { s. } \\
-2\end{array}$ & है & : & $\frac{\mathrm{s}}{\mathrm{s}}$ & హ్ & జ2: & $\begin{array}{l}\text { \%े } \\
\text { के }\end{array}$ & $\stackrel{\circ}{\circ}$ \\
\hline & & $\bar{z}$ & & $\vec{m}$ & $\infty$ & $=$ & & $=$ & $\overline{4}$ & $\stackrel{20}{\varrho}$ & 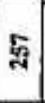 & ฐू & 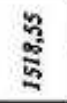 & & 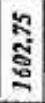 & $\frac{n}{a}$ \\
\hline & \multirow{2}{*}{ 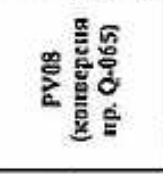 } & $\therefore$ & & $\stackrel{\circ}{m}$ & $\begin{array}{l}\text { वें } \\
\text {. }\end{array}$ & $\begin{array}{l}0 \\
\vdots \\
0\end{array}$ & & 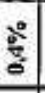 & s: & ڤ. & 今. & 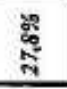 & 学 & $\begin{array}{l}3: \\
3 \\
3 \\
3\end{array}$ & $\frac{\dot{m}}{m}$ & ذِّ \\
\hline & & $z$ & & $\cong$ & $\infty$ & $=$ & & $=$ & $=$ & 亘 & 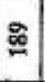 & હેँ & है & స్త్ & ฏ્ڤ & ఫ్ \\
\hline & \multirow{2}{*}{ 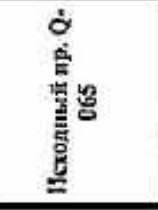 } & $\therefore$ & & 今 & ఫ్షే) & $\begin{array}{l}0 \\
5 \\
5 \\
5\end{array}$ & & 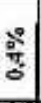 & 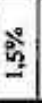 & స్. & 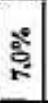 & है & $\frac{30}{\frac{3}{2}}$ & 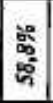 & $\stackrel{\text { : }}{*}$ & : \\
\hline & & "z & & $\overline{3}$ & $\infty$ & 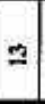 & & $=$ & is & 능 & $\mathbb{N}_{\mathbb{N}}$ & 管 & ถู & ఫ్ & 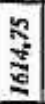 & $\frac{n}{5}$ \\
\hline \multirow{8}{*}{ 䓂 } & \multirow{2}{*}{ 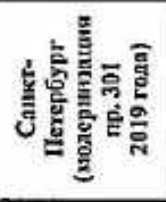 } & $\Delta^{\circ}$ & : & ڤ્ & 窇 & ฉे? & & 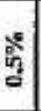 & ؛े & ลे & 党 & $\begin{array}{l}\text { ఫे } \\
\text { ळे }\end{array}$ & ঐे & ఫे & 空 & है \\
\hline & & $y$ & ন & $\Xi$ & $\approx$ & \& & & $\approx$ & $F$ & $\Xi$ & 点 & 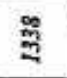 & $\underset{\sim}{\mathbb{్}}$ & ฐิे & : & ఫ్ \\
\hline & \multirow{2}{*}{ 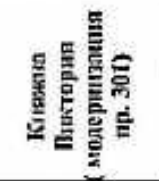 } & $\therefore$ & : & 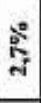 & 今े & ఫ్ & & 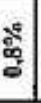 & $\stackrel{2}{2}$ & बें & 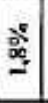 & हूँ & $\begin{array}{l}\text { హे } \\
\text { wh }\end{array}$ & $\begin{array}{l}32 \\
2 \\
3\end{array}$ & 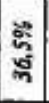 & ذ్్ㄹㅇ \\
\hline & & $z$ & ฉิ & $\bar{\Phi}$ & 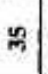 & 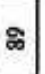 & & E) & $\infty$ & $\stackrel{n}{\leftrightarrows}$ & $\stackrel{\oplus}{9}$ & 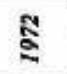 & ६ุ & ह్ & ث্ & $\frac{}{k}$ \\
\hline & \multirow{2}{*}{ 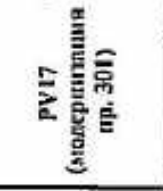 } & $\approx$ & 递 & हैं & 贵 & ఫे| & & 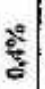 & ఫ્ & ذ્ّ & ‡్ & $\begin{array}{l}\text { 葛 } \\
\text { 战 }\end{array}$ & :ू & & 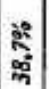 & ذ্ \\
\hline & & $\bar{z}$ & ₹ & $\bar{\Xi}$ & $\stackrel{m}{m}$ & \&) & & $\approx$ & $\approx$ & $\stackrel{4}{2}$ & in & ڤ్ & 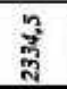 & $\begin{array}{l}\text { के } \\
\text { के }\end{array}$ & 츷 & है \\
\hline & \multirow{2}{*}{ 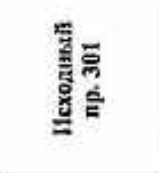 } & $\therefore$ & 究 & 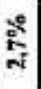 & $\begin{array}{l}0 \\
0 \\
0 \\
0\end{array}$ & 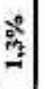 & & ఫิ? & 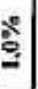 & $\stackrel{\circ}{=}$ & $\stackrel{\circ}{\circ}$ & 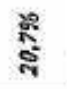 & $\begin{array}{l}\text { 恣 } \\
5\end{array}$ & $\begin{array}{l}\frac{2}{2} \\
\frac{1}{6}\end{array}$ & 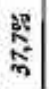 & ఏे \\
\hline & & $\bar{z}$ & त) & $\Xi$ & $\stackrel{10}{\circ}$ & ळ & & $\Rightarrow$ & $F$ & 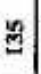 & $\bar{s}$ & 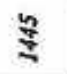 & ฐิ๊ & $\frac{1}{7}$ & สัฒ & ఫ్ \\
\hline & 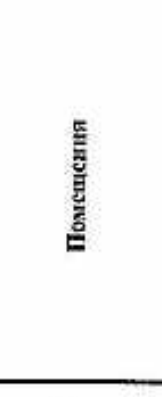 & & 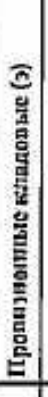 & 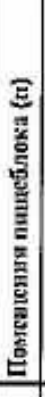 & 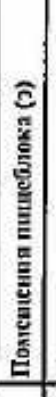 & 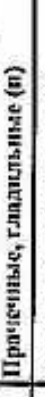 & 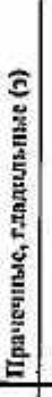 & 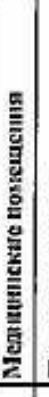 & 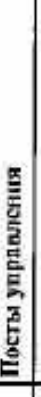 & 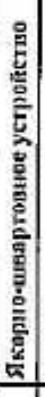 & 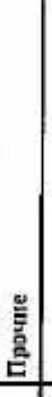 & 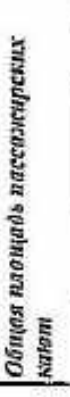 & 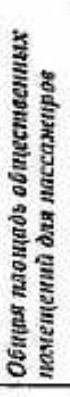 & 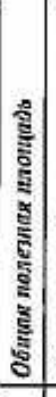 & 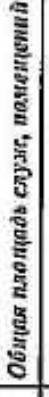 & 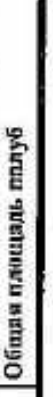 \\
\hline & 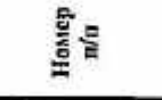 & & 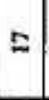 & 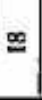 & 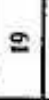 & तิ & $\overline{\mathbf{N}}$ & స & F & $\not$ & 2 & 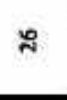 & A & & ‡ి & \\
\hline
\end{tabular}


HERALD

ปู

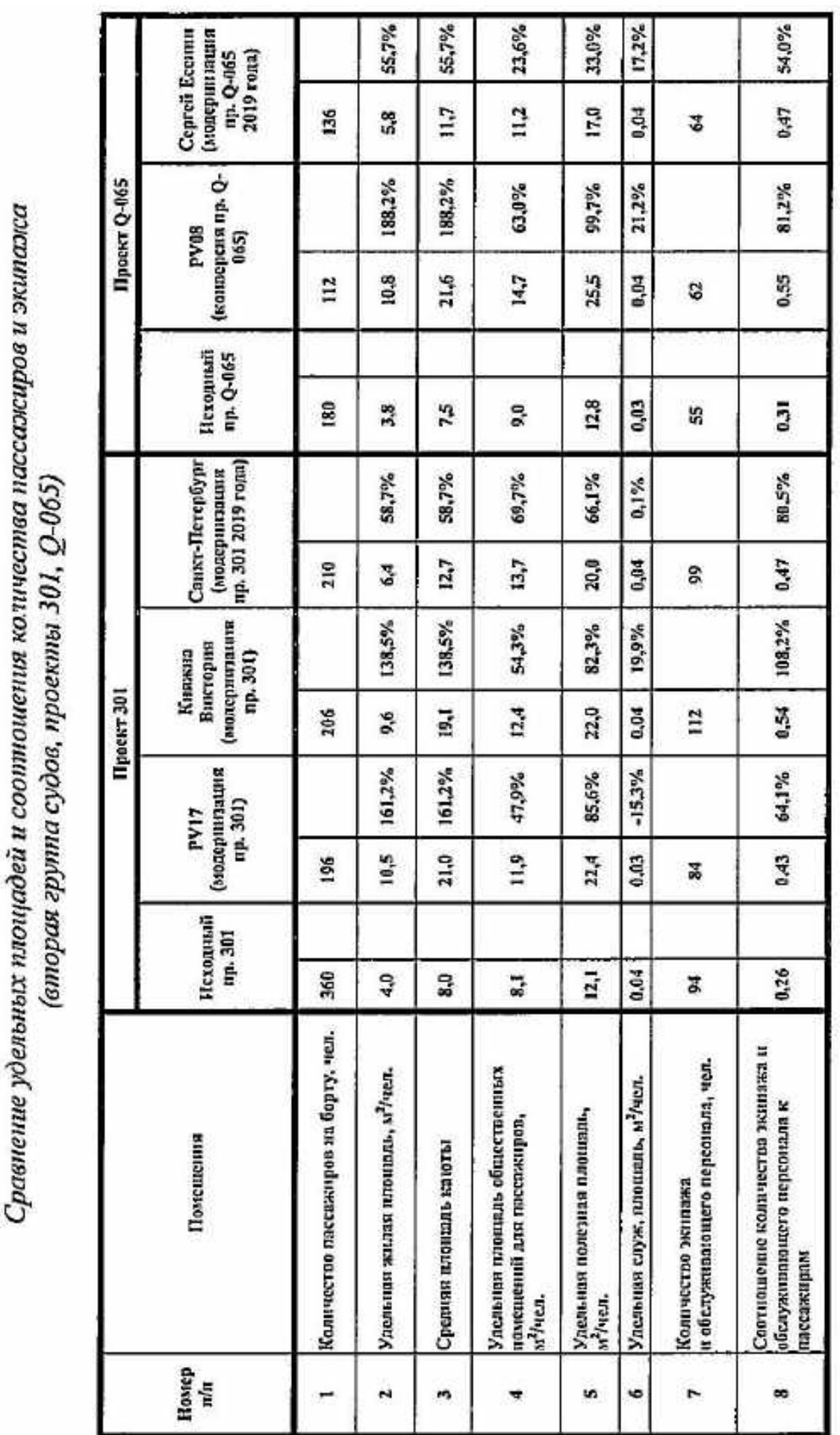


क

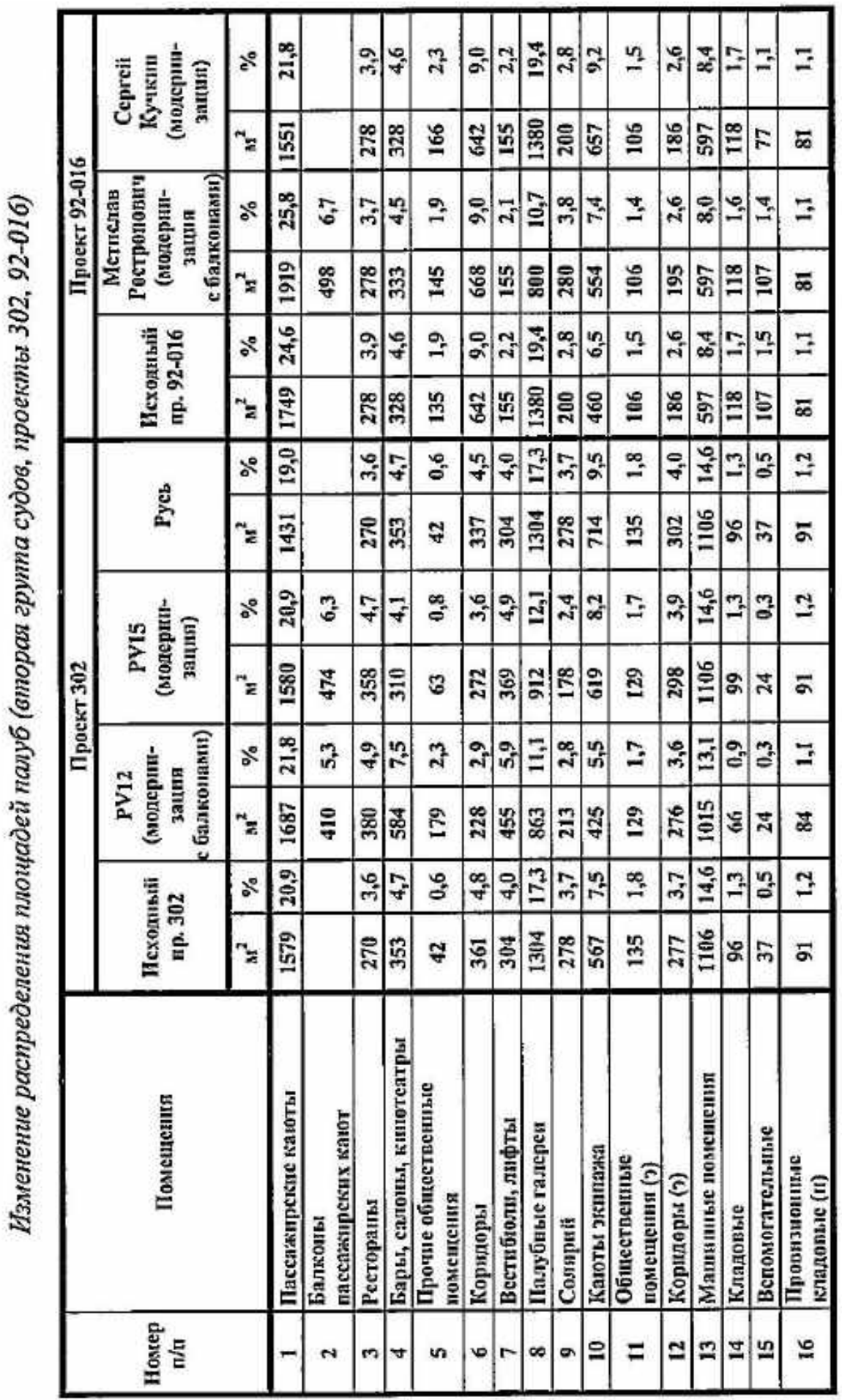




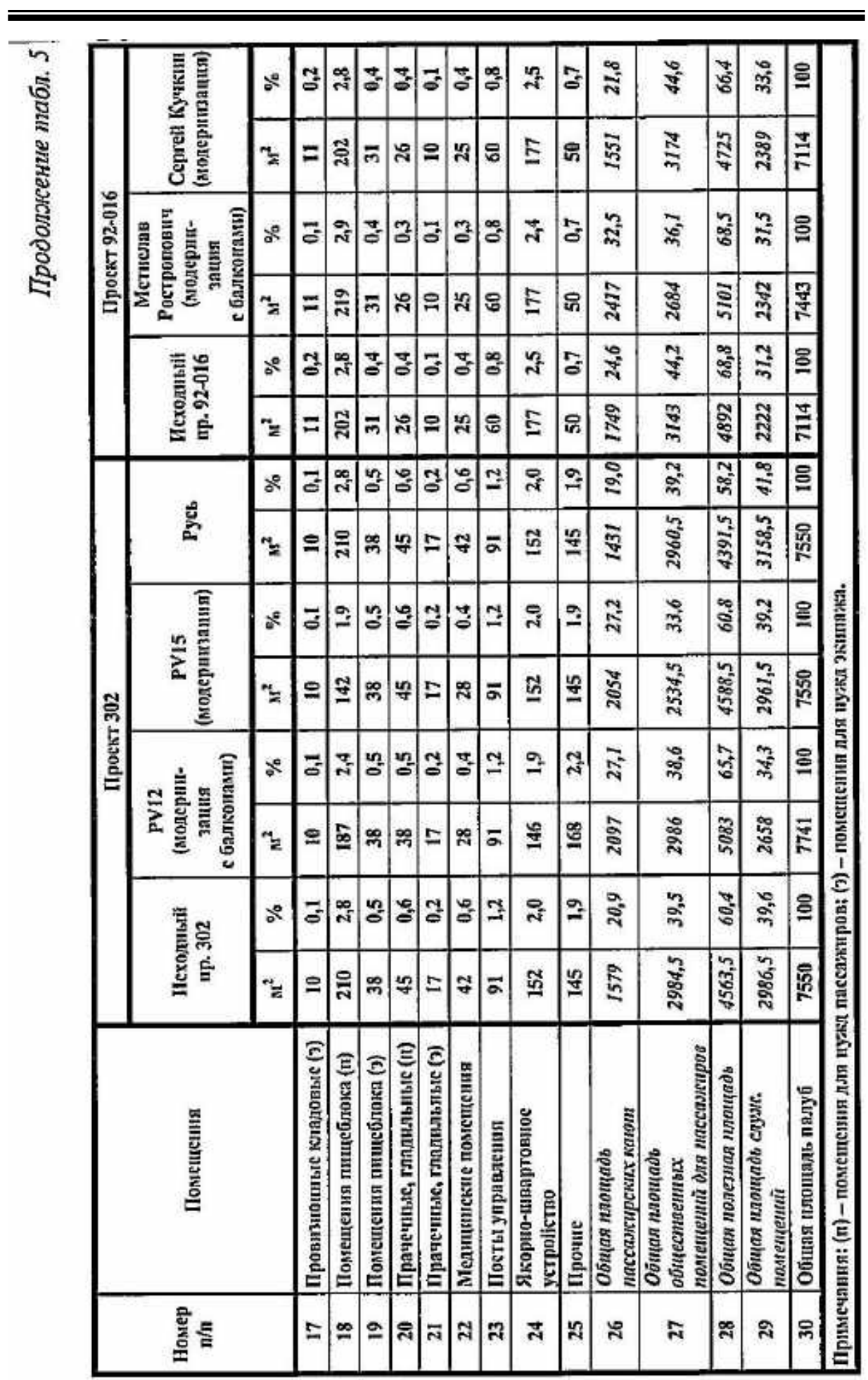




\begin{tabular}{|c|c|c|c|c|c|c|c|c|c|c|}
\hline \multirow{2}{*}{ 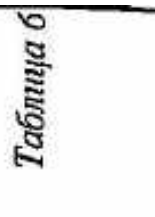 } & \multirow{6}{*}{ 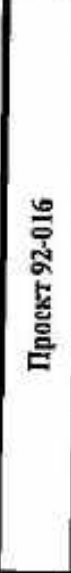 } & \multirow{2}{*}{ 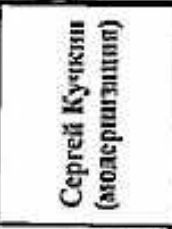 } & & 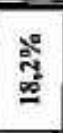 & 网 & $\begin{array}{l}\text { :ें } \\
\text { অे }\end{array}$ & $\begin{array}{l}\stackrel{\circ}{\circ} \\
\text { హే }\end{array}$ & 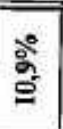 & & ڤั: \\
\hline & & & ి్లి & ำ & $\underline{\underline{S}}$ & $\stackrel{\circ}{\Xi}$ & 象 & 홍 & \& & $\frac{\pi}{2}$ \\
\hline \multirow{4}{*}{ 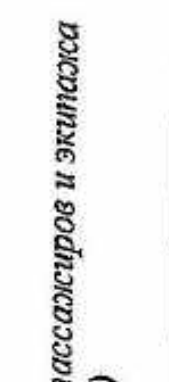 } & & \multirow{2}{*}{ 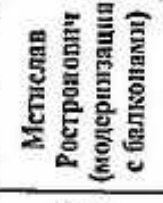 } & & ڤ్ & ڤั̊ & $\stackrel{\circ}{0}$ & 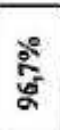 & 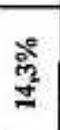 & & 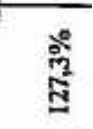 \\
\hline & & & สี & \pm & స్ & $\mathrm{g}$ & $\bar{z}$ & 형 & 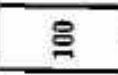 & E \\
\hline & & \multirow{2}{*}{ 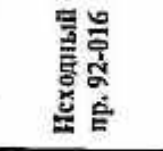 } & & & & & & & & \\
\hline & & & ళ్ & 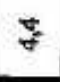 & के & : & $\stackrel{q}{\Xi}$ & $\stackrel{\Xi}{\circ}$ & $\approx$ & స్ \\
\hline \multirow{8}{*}{ 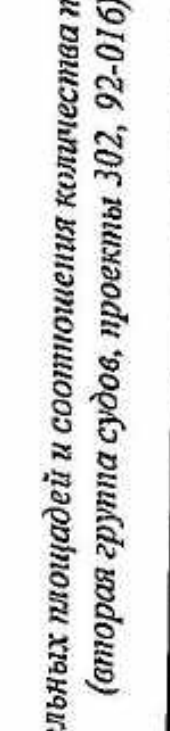 } & \multirow{8}{*}{$\begin{array}{l}\text { s: } \\
\text { 点 } \\
\text { 总 } \\
\end{array}$} & \multirow{2}{*}{$\hat{\mathrm{E}}$} & & 趈 & 总 & $\begin{array}{l}\text { 今. } \\
\text { : }\end{array}$ & $\begin{array}{l}\mathrm{m}^{\circ} \\
m^{2}\end{array}$ & : & & $\begin{array}{l}\text { 今े } \\
\text { ज్ } \\
\text { जू }\end{array}$ \\
\hline & & & జี & का & $\bar{\Xi}$ & $\stackrel{w_{2}}{=}$ & $\begin{array}{l}\text { 足 } \\
\text { in }\end{array}$ & $\stackrel{0}{\circ}$ & §ิ & $\frac{6}{6}$ \\
\hline & & \multirow{2}{*}{ 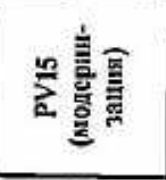 } & & 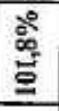 & 今 & $\frac{0}{5}$ & 离 & $\frac{5}{65}$ & & $\frac{5}{6}$ \\
\hline & & & $\frac{\vec{H}}{N}$ & $\approx$ & ㄴ & $\stackrel{\infty}{=}$ & $\vec{N}$ & $\ddot{\circ}$ & : & 웅 \\
\hline & & \multirow{2}{*}{ 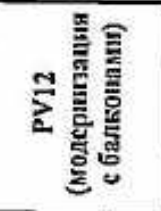 } & & 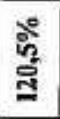 & 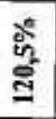 & ‡ั & $\frac{\grave{\alpha}}{\not ்}$ & $\stackrel{\varrho}{\Xi}$ & & $\frac{\partial}{20}$ \\
\hline & & & ฮి & $\stackrel{n}{=}$ & $\frac{9}{\pi}$ & $\frac{a}{\dot{y}}$ & से & $\stackrel{D}{g}$ & : & है \\
\hline & & \multirow{2}{*}{ 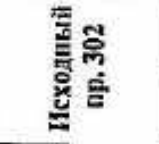 } & & & & & & & & \\
\hline & & & గ్లు & $\stackrel{\infty}{+}$ & $\approx$ & है & $=$ & : & से & శ్ \\
\hline \multirow[t]{2}{*}{ 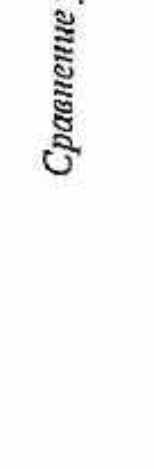 } & & 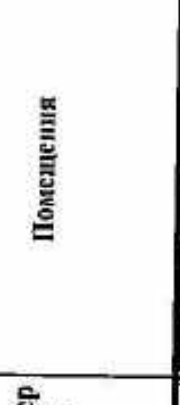 & 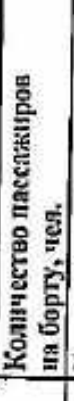 & 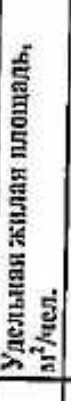 & 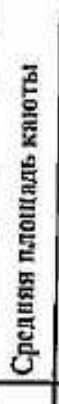 & 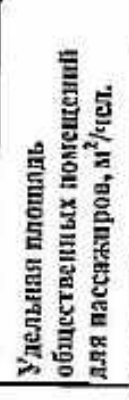 & 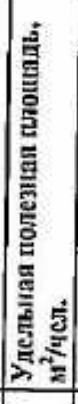 & 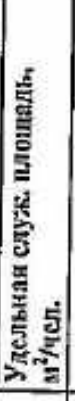 & 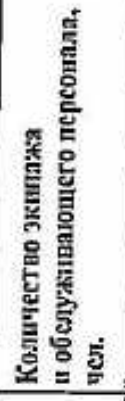 & 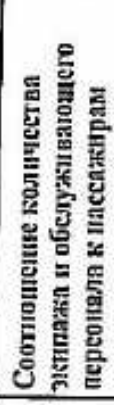 \\
\hline & & 总总 & - & $N$ & $m$ & + & in & 6 & r & \\
\hline
\end{tabular}




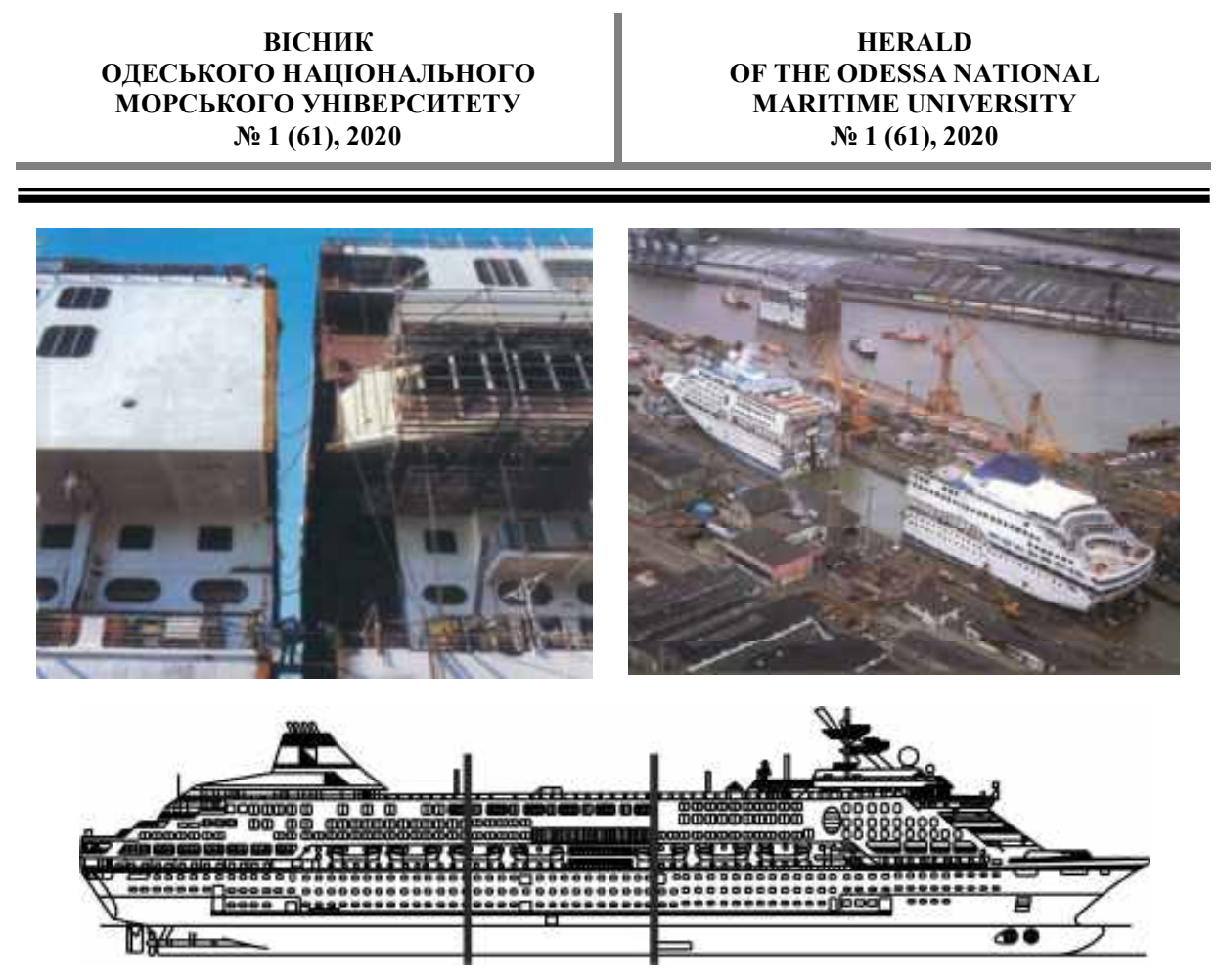

Рис. 1. Пример размерной модернизаџии морского круизного пассажирского судна [7]

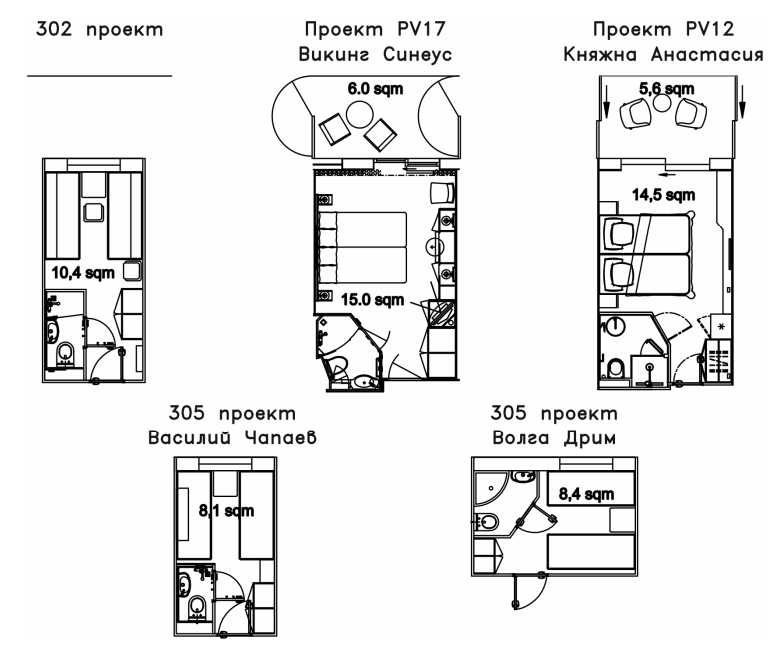

Рис. 2. Изменение площадей и компоновки пассажирских кают на РКПС первой (проект 305) и второй групп (проект 302)

Изменение площадей и компоновки ресторанного комплекса (увеличение общей площади, а также количества ресторанов) на примере проекта 302 и его модификаций (проекты PV12, PV17 Морского Инженерного Бюро) представлено на рисунке 6. 
ВІСНИК

ОДЕСЬКОГО НАЦІОНАЛЬНОГО

МОРСЬКОГО УНІВЕРСИТЕТУ

№ 1 (61), 2020
HERALD

OF THE ODESSA NATIONAL

MARITIME UNIVERSITY № 1 (61), 2020

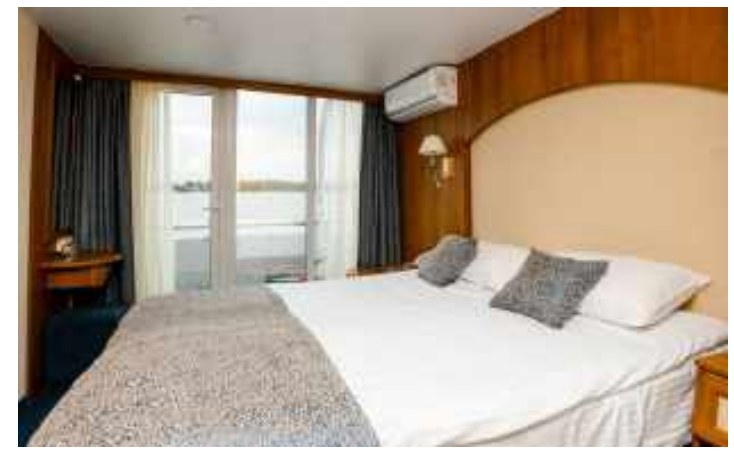

Рис. 3. Общий вид каюты на модернизированном $m / x$ «A.С. Попов» (проект 588) [10]

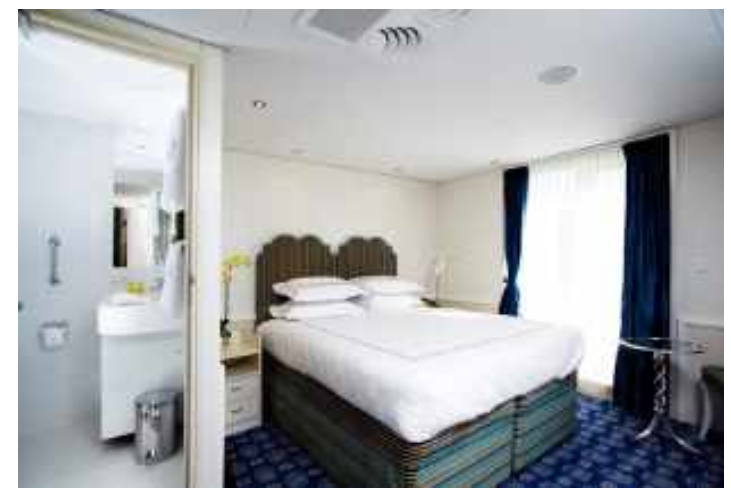

Рис. 4. Общчий вид каюты на модернизированном $m / x$ «Княжна Виктория» (проект 301) [11]

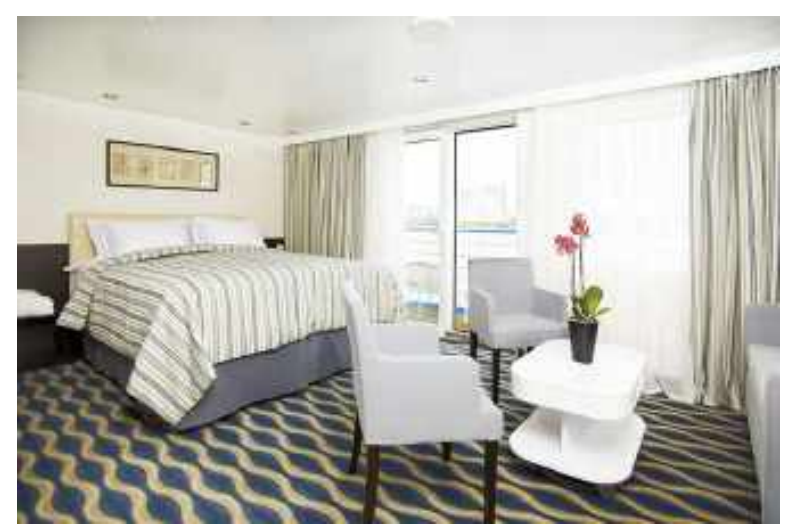

Рис. 5. Общий вид каюты на конверсионном $m / x$ «Александр Грин» (проект PV08) [11] 


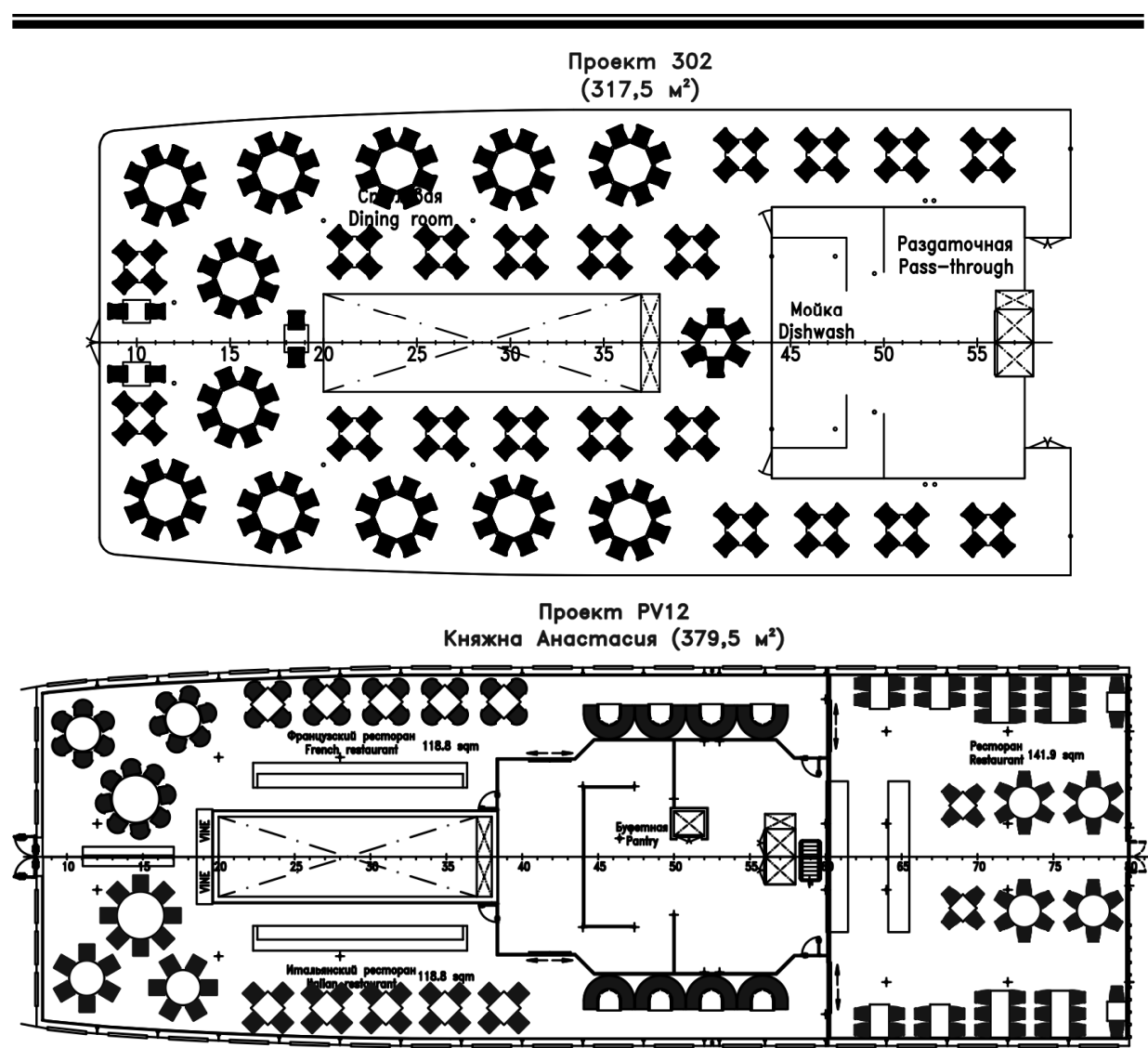

Проекm PV17

Buкuне Синеус $\left(353 \mathrm{~m}^{2}\right)$

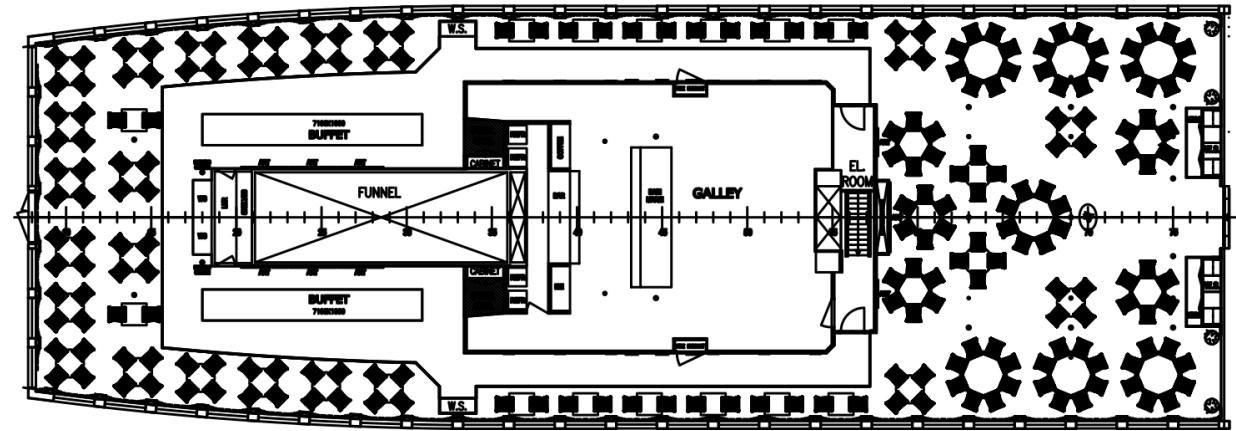

Рис. 6. Изменение площуадей и компоновки ресторана на РКПС проекта 302

Такие модернизации ресторанного комплекса характерны и для европейского речного круизного рынка. Например, один из лидеров сегмента, круизная компания Nicko Cruises, в ущерб пассажировместимости 
в крайние годы расширяет ресторанный комплекс, предлагая 3 различных ресторана на борту [4].

Количество всех палуб $n$ на проектируемых или модернизируемых РКПС, включая палубы для размещения экипажа и служебных помещений, а также солнечную палубу, можно определять в зависимости от $L B, \mathrm{~m}^{2}$ (где $L$ и $B$ - габаритная длина и ширина РКПС соответственно) следующим: три палубы ( $n=3)$ при $L B=1100-1250$ м $^{2}$, четыре палубы $(n=4)$ при $L B=1250-1500 \mathrm{~m}^{2}$, пять палуб $(n=5)$ при $L B=1500 \div 2350 \mathrm{м}^{2}$ и шесть палуб $(n=6)$ при $L B=2350-2400 \mathrm{~m}^{2}$.

Для определения коэффициента утилизации общей площади палуб $s_{\text {nалуб }}=S_{\text {nалуб }} / L B n$ на РКПС (для всех судов, базовых и модернизированных) была получена зависимость $s_{\text {nалуб }}=3,5583 \cdot(L B n)^{-0,18}$ (см. рисунок 7).

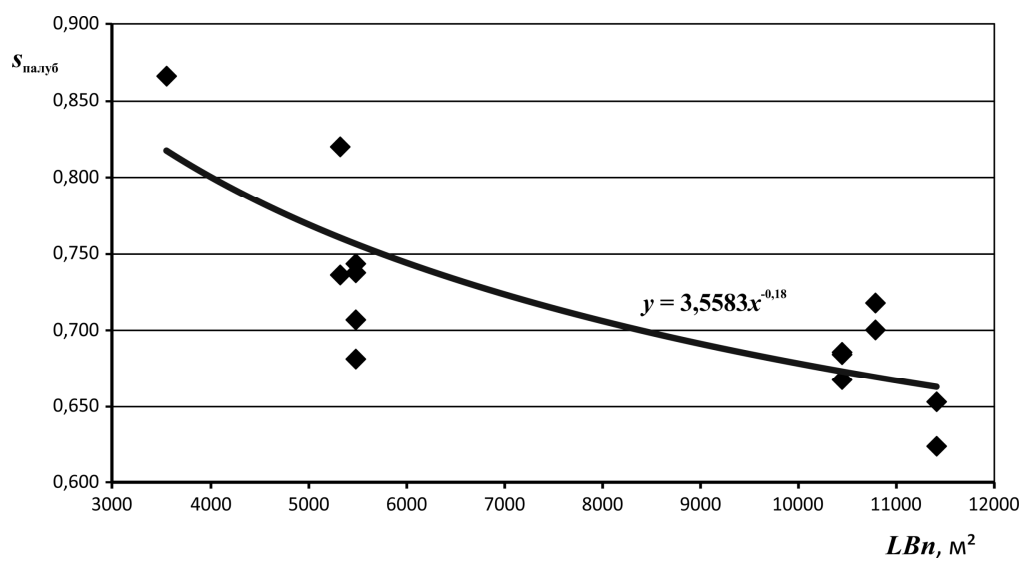

Рис. 7. Определение коэффициента утилизащии общей площади палуб $s_{\text {палуб }}$

Средняя площадь пассажирской каюты на конверсионном РКПС проекта PV06 по сравнению с исходным судном проекта 588 выросла на 196,7 \% (с 4,1 м² до 12,2 м²), на «Руси Великой» - на 170,8 \% (до 11,2 м²), на модернизированном «И.А. Крылове» - на 121,8 \% (до 9,2 м²).

На модернизированном «Сергее Образцове» по сравнению с исходным судном проекта 305 - на $104,8 \%$ (с 3,3 м² до 6,7 м $^{2}$ ).

На модернизированном РКПС проекта PV17 по сравнению с исходным судном проекта 301 - на 161,2 \% (с 8,0 м до 21,0 м²), на «Княжне Виктории» - на 138,5 \% (до 19,1 м²); на «Санкт-Петербурге» на $58,7 \%$ (до $12,7 \mathrm{~m}^{2}$ ).

На конверсионном РКПС проекта PV08 по сравнению с исходным судном проекта Q-065 - на 188,2 \% (с 7,5 м² до 21,6 м²), на модернизированном «Сергее Есенине» - на 55,7 \% (до 11,7 м²). 
На модернизированном РКПС проекта PV12 по сравнению с исходным судном проекта 302 - на 120,5 \% (с 9,5 м до 21,0 м²), на модернизированном судне проекта PV15 - на 101,8 \% (до 19,2 м²), на $\mathrm{T} / \mathrm{x}$ «Русь» - на 6,7 \% (до 10,1 м²).

На «Мстиславе Ростроповиче» по сравнению с исходным судном проекта 92-016 - на 160,7 \% (с 8,7 м² до 22,8 м²), на «Сергее Кучкине» на $18,2 \%$ (до $\left.10,3 \mathrm{~m}^{2}\right)$.

Зависимости для средних значений площадей пассажирских кают $S_{\kappa}$ у базовых и модернизированных проектов приведены на рисунке 8.

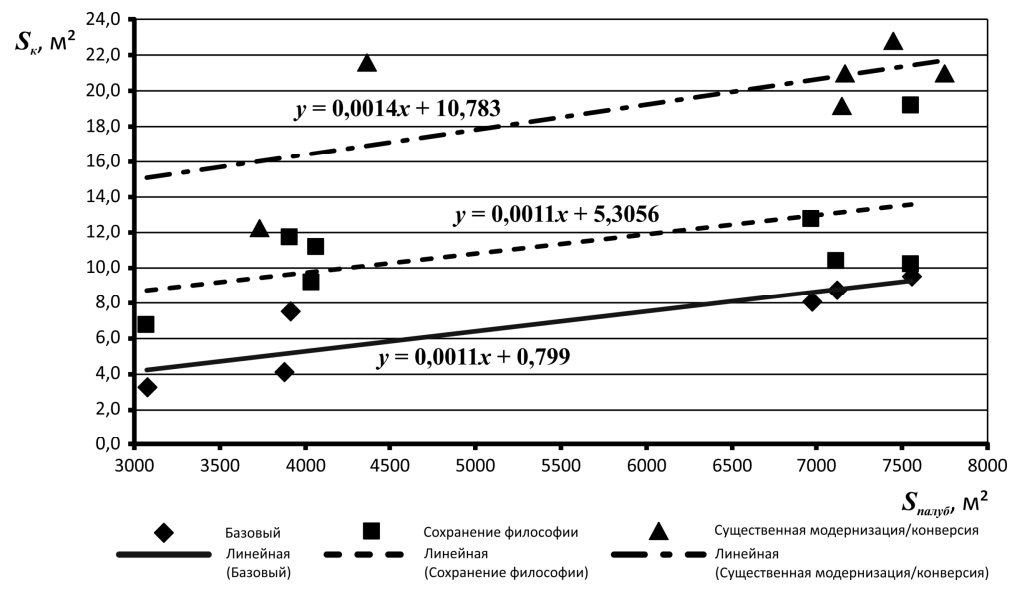

Рис. 8. Определение среднего значения площадей пассажирских кают $S_{\kappa}, \mu^{2}$

Для базовых проектов эта зависимость может быть представлена как $S_{\kappa}=0,0011 \cdot S_{\text {naлy }}+0,799, \mathrm{~m}^{2}$, для проектов с сохранением философии - $S_{\kappa}=0,0011 \cdot S_{\text {nалуб }}+5,3056, \mathrm{~m}^{2}$, для существенных модернизаций и конверсий $-S_{\kappa}=0,0014 \cdot S_{\text {navy }}+10,783, \mathrm{M}^{2}$.

Значения удельной площади (отнесенной к количеству пассажиров) пассажирских кают $S_{\kappa}^{\prime}$ для всех судов, базовых и модернизированных, приведены на рисунке 9 и могут быть определены по зависимости

$$
S_{\kappa}^{\prime}=0,0069 \cdot\left(\frac{S_{\text {nayy }}}{N_{\text {nac }}}\right)^{2}-0,033 \cdot \frac{S_{\text {naxy }}}{N_{\text {nас }}}+1,8688, \mathrm{M}^{2} / \text { чел. }
$$

Удельная площадь общественных помещений на конверсионном РКПС проекта PV06 по сравнению с исходным судном проекта 588 выросла на 232,3 \% (с 4,7 м²/чел до 15,7 м²/чел), на «Руси Великой» - на $91,8 \%$ (до 9,1 м²/чел), на модернизированном «И.А. Крылове» - на 92,1 \% (до $9,1 \mathrm{~m}^{2} /$ чел). 
ВІСНИК

ОДЕСЬКОГО НАЦІОНАЛЬНОГО

МОРСЬКОГО УНІВЕРСИТЕТУ

№ 1 (61), 2020
HERALD

OF THE ODESSA NATIONAL

MARITIME UNIVERSITY № 1 (61), 2020

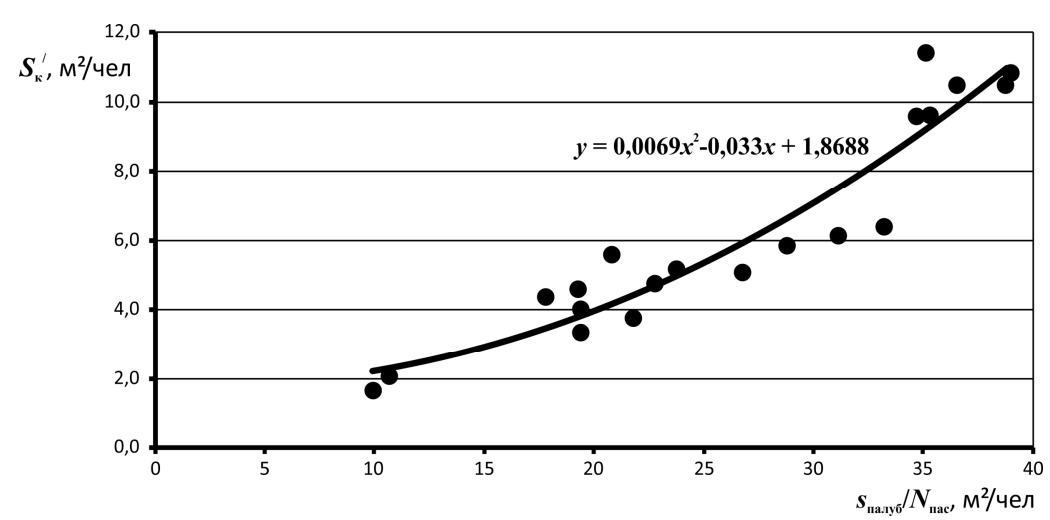

Рис. 9. Определение значений удельных площчадей пассажирских кают $S_{\kappa}^{\prime}, м^{2} /$ чел.

На модернизированном «Сергее Образцове» по сравнению с исходным судном проекта 305 - на 93,8 \% (с 5,2 м²/чел до 10,1 м²/чел).

На модернизированном РКПС проекта PV17 по сравнению с исходным судном проекта 301 - на 47,9 \% (с 8,1 м²/чел до 11,9 м²/чел), на «Княжне Виктории» - на $54,3 \%$ (до $12,4 \mathrm{~m}^{2} /$ чел); на «СанктПетербурге» - на 69,7 \% (до 13,7 м²/чел).

На конверсионном РКПС проекта PV08 по сравнению с исходным судном проекта Q-065 - на 63,0 \% (с 9,0 м²/чел до 14,7 м²/чел), на модернизированном «Сергее Есенине» - на 23,6 \% (до 11,2 м²/чел).

На модернизированном РКПС проекта PV12 по сравнению с исходным судном проекта 302 - на 66,1 \% (с 9,0 м²/чел до 14,9 м²/чел), на модернизированном судне проекта PV15 - на 31,7 \% (до 11,8 м²/чел), на т/х «Русь» - на 16,8 \% (до 10,5 м²/чел).

На «Мстиславе Ростроповиче» по сравнению с исходным судном

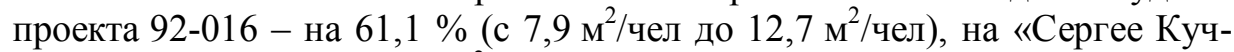
кине» - на 34,6 \% (до 10,6 м²/чел).

Значения удельных площадей общественных помещений $S_{o}^{\prime}$ для всех судов, базовых и модернизированных, приведены на рисунке 10 и могут быть определены по зависимости $S_{o}^{\prime}=0,306 \cdot \frac{S_{\text {navy }}}{N_{\text {nac }}}+2,5933, \mathrm{M}^{2} /$ чел.

Удельная полезная площадь (площадь общественных помещений для пассажира и кают) на конверсионном РКПС проекта PV06 по сравнению с исходным судном проекта 588 выросла на $221,5 \%$ (с 6,8 м²/чел. до $21,8 \mathrm{~m}^{2} /$ чел.), на «Руси Великой» - на $115,8 \%$ (до 14,7 м²/чел.), на модернизированном «И.А. Крылове» - на 101,1 \% (до 13,7 м²/чел.). 


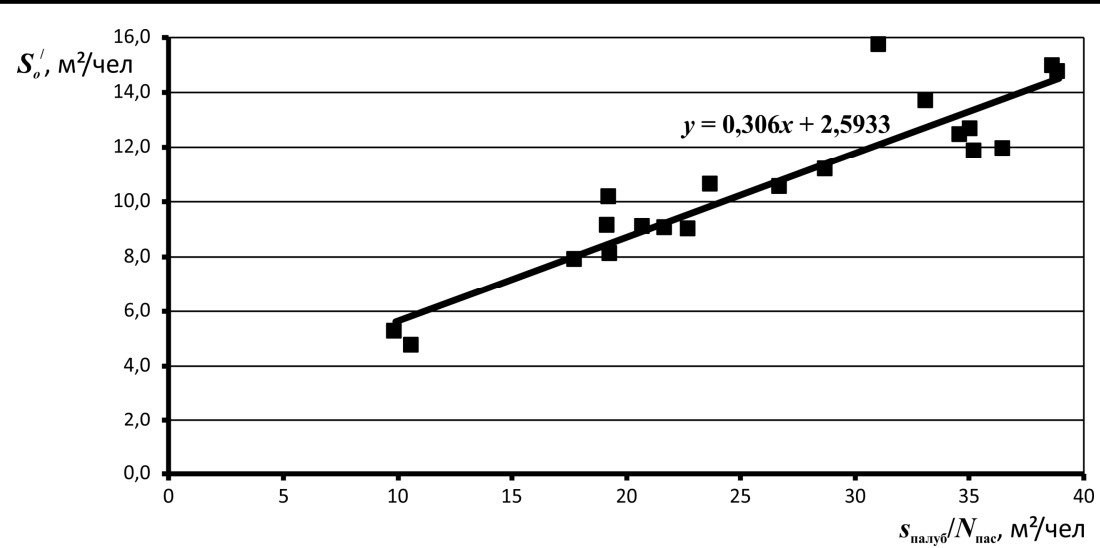

Рис. 10. Определение значений удельных площадей

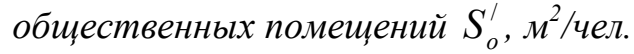

На модернизированном «Сергее Образцове» по сравнению с исходным судном проекта 305 - на 96,4 \% (с 6,9 м²/чел. до 13,5 м²/чел.).

На модернизированном РКПС проекта PV17 по сравнению с исходным судном проекта 301 - на 85,6 \% (с 12,1 м²/чел. до 22,4 м²/чел.), на «Княжне Виктории» - на $82,3 \%$ (до $22,0 \mathrm{~m}^{2} /$ чел.); на «СанктПетербурге» - на 66,1% (до 20,0 м²/чел.).

На конверсионном РКПС проекта PV08 по сравнению с исходным судном проекта Q-065 - на 99,7 \% (с 12,8 м²/чел. до 25,5 м²/чел.), на модернизированном «Сергее Есенине» - на 33,0 \% (до 17,0 м²/чел.).

На модернизированном РКПС проекта PV12 по сравнению с исходным судном проекта 302 - на 84,9 \% (с 13,7 м²/чел. до 25,4 м²/чел.), на модернизированном судне проекта PV15 - на 56,0 \% (до 21,4 м²/чел.), на т/х «Русь» - на 13,3 \% (до 15,6 м²/чел.).

На «Мстиславе Ростроповиче» по сравнению с исходным судном проекта 92-016 - на 96,7 \% (с 12,2 м²/чел. до $24,1 \mathrm{~m}^{2} /$ чел.), на «Сергее Кучкине» - на 28,8 \% (до 15,8 м²/чел.).

Значения удельных полезных (пассажирские каюты и общественные помещения) площадей $S_{n о л}^{\prime}$ для всех судов, базовых и модернизированных, приведены на рисунке 11 и могут быть определены по зависимости $S_{\text {пол }}^{\prime}=0,6225 \cdot \frac{S_{\text {naxy } \sigma}}{N_{\text {nac }}}+0,5468, \mathrm{~m}^{2} /$ чел.

Коэффициент утилизации полезных площадей для базовых проектов $-s_{\text {nол }}=0,8379 \cdot\left(S_{\text {naлy }}\right)^{-0,032}$, для проектов с сохранением философии $S_{\text {пол }}=1,0655 \cdot\left(S_{\text {nалуб }}\right)^{-0,058}$, для существенных модернизаций и конверсий $S_{\text {no: }}=1,3861 \cdot\left(S_{\text {naxy }}\right)^{-0,086}$. 


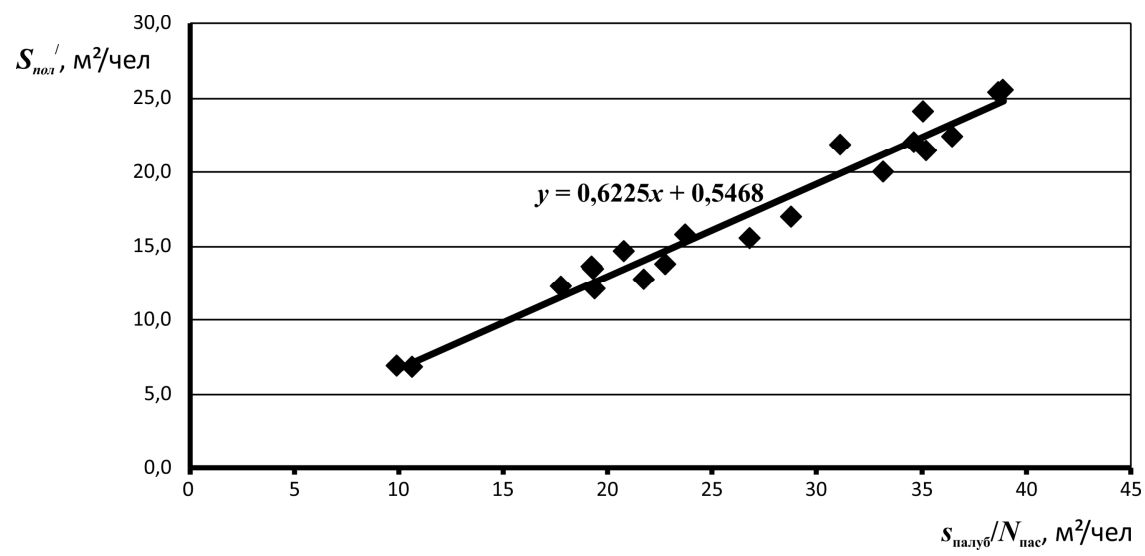

Рис. 11. Определение значений удельных полезных площчадей $S_{\text {пол }}^{\prime}, \mathrm{M}^{2} /$ чел.

Было установлено, что для значений удельных площадей (рисунки 9-11) характерны следующие значения отношений:

$S_{\text {naлуб }} / N_{\text {nac }}=9-22 \mathrm{~m}^{2} /$ чел. - базовые проекты РКПС;

$S_{\text {nалуб }} / N_{\text {nac }}=22-35 \mathrm{~m}^{2} /$ чел. - проекты с сохранением философии;

$S_{\text {nалуб }} / N_{\text {nас }}=35-40 \mathrm{~m}^{2} /$ чел. - существенные модернизации и конверсии.

Анализ распределения площадей палуб (таблицы 1-6) позволил получить также коэффициенты утилизации площадей пассажирских кают $S_{\kappa}=S_{\kappa} / S_{\text {nалуб }}$ (см. рисунок 12), общественных помещений $S_{o}=S_{o} / S_{\text {nалуб }}$ (см. рисунок 13), полезных площадей $S_{\text {пол }}=S_{\text {пол }} / S_{\text {палуб }}$ (см. рисунок 14) и служебных помещений $S_{c л}=S_{c л} / S_{\text {палуб }}$ (см. рисунок 15), причем как для базовых, так и модернизированных проектов.

Коэффициент утилизации площадей пассажирских кают для базовых проектов $s_{\kappa}=0,0131 \cdot\left(S_{\text {naxy }}\right)^{0,3175}$, для проектов с сохранением философии может быть определен как $s_{\kappa}=0,0344 \cdot\left(S_{\text {navy }}\right)^{0,2166}$, для существенных модернизаций и конверсий $-s_{k}=0,0162 \cdot\left(S_{\text {naхуб }}\right)^{0,3242}$.

Коэффициент утилизации общественных помещений для базовых проектов $-s_{o}=2,0662 \cdot\left(S_{\text {naуy }}\right)^{-0,182}$, для проектов с сохранением философии $s_{o}=3,3845 \cdot\left(S_{\text {nay }}\right)^{-0,243}$, для существенных модернизаций и конверсий $s_{o}=6,2251 \cdot\left(S_{\text {naxy }}\right)^{-0,321}$. 
ВІСНИК

ОДЕСЬКОГО НАЦІОНАЛЬНОГО МОРСЬКОГО УНІВЕРСИТЕТУ № 1 (61), 2020
HERALD

OF THE ODESSA NATIONAL MARITIME UNIVERSITY № 1 (61), 2020

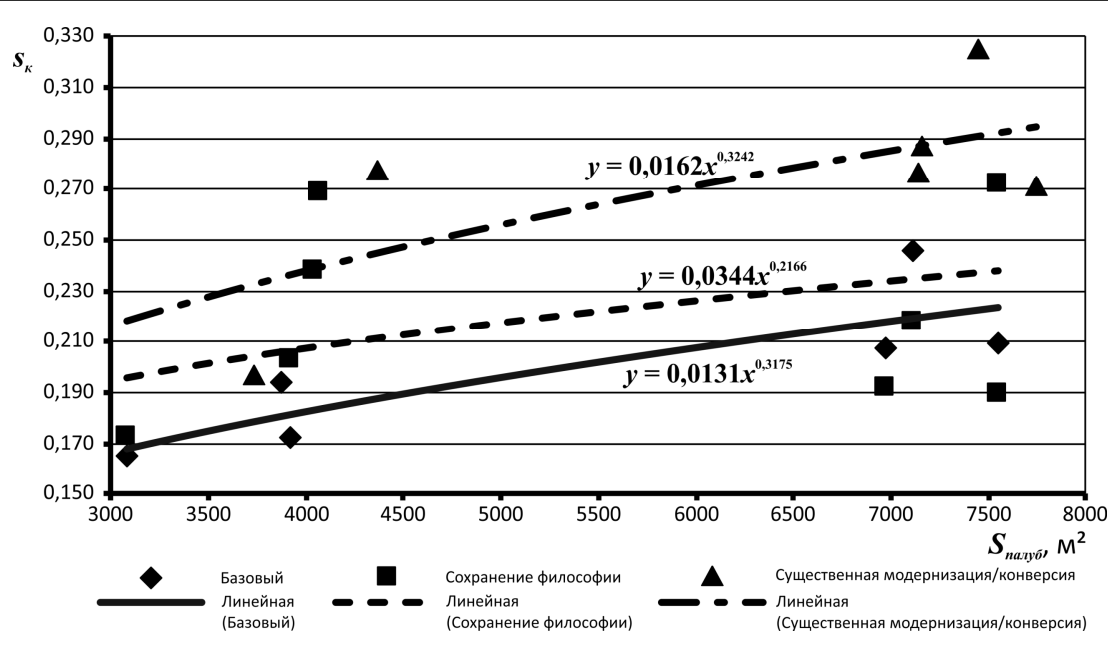

Рис. 12. Определение коэффициента утилизации площฺадей пассажирских кают $S_{\kappa}$

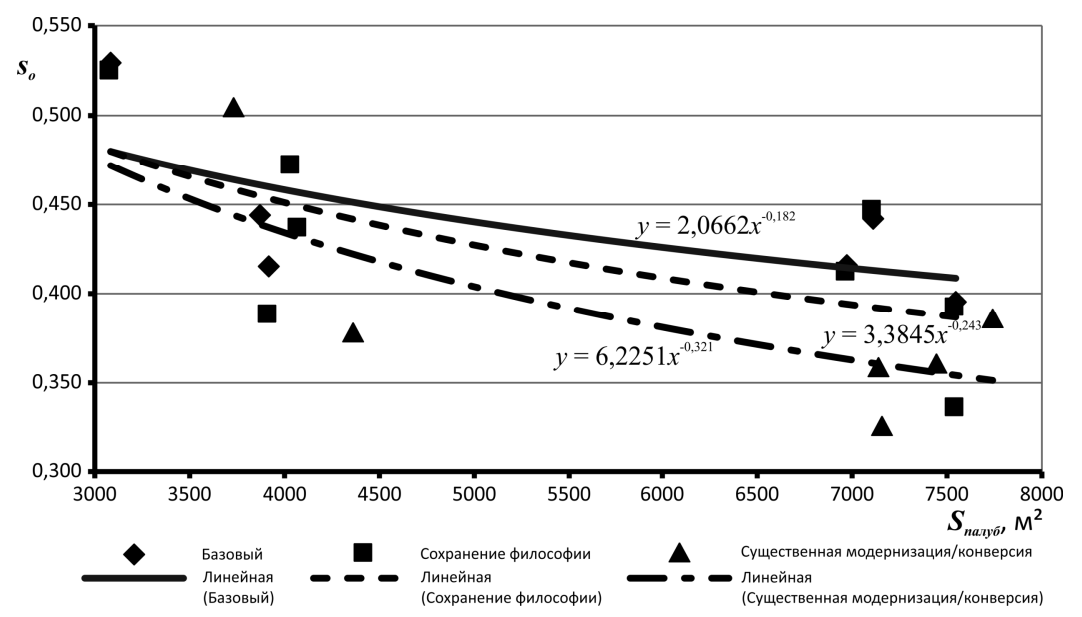

Рис. 13. Определение коэффициента утилизации общественных помещений $s_{\text {o }}$ 
ВІСНИК

ОДЕСЬКОГО НАЦІОНАЛЬНОГО МОРСЬКОГО УНІВЕРСИТЕТУ № 1 (61), 2020
HERALD

OF THE ODESSA NATIONAL

MARITIME UNIVERSITY № 1 (61), 2020

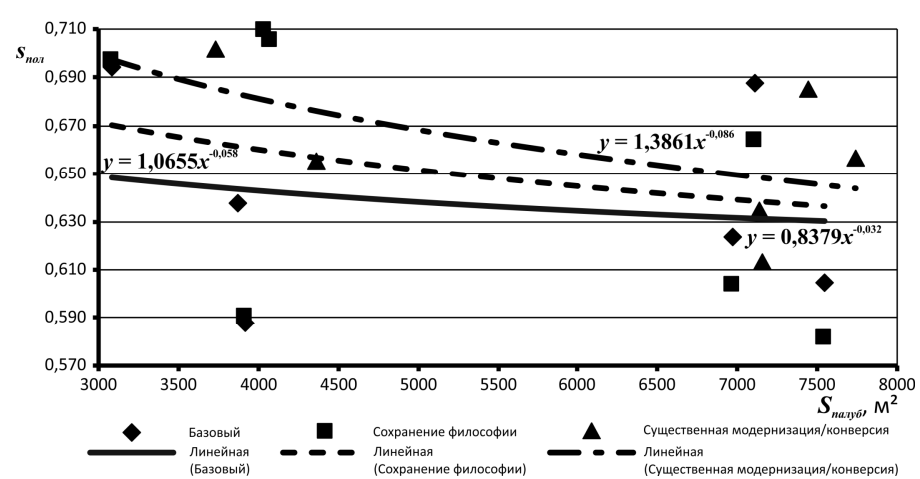

Рис. 14. Определение коэффициента утилизациии полезных помещчений $S_{\text {пол }}$

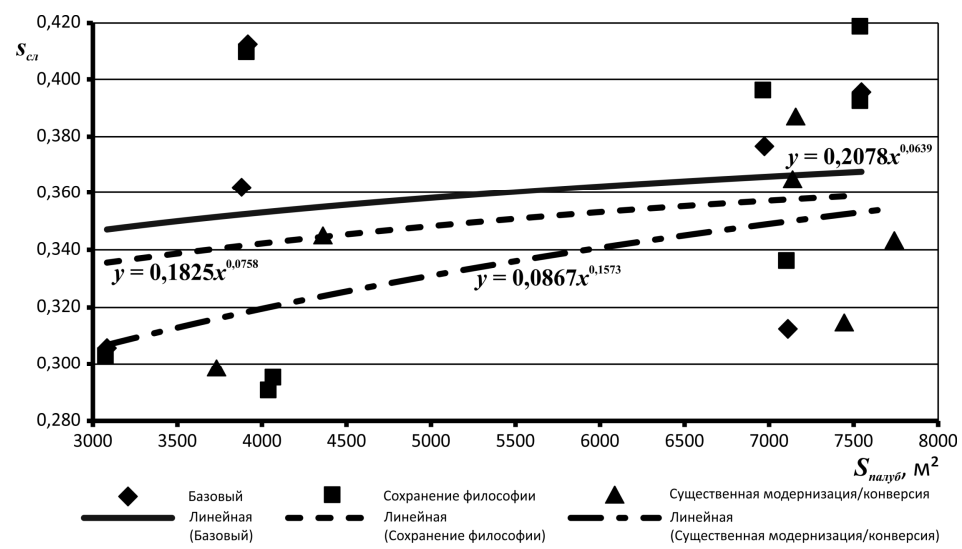

Рис. 15. Определение коэффициента утилизациии служебных помещений $s_{c л}$

Коэффициент утилизации служебных площадей для базовых проектов $-s_{c л}=0,2078 \cdot\left(S_{\text {nалv }}\right)^{0,0639}$, для проектов с сохранением философии $-S_{c л}=0,1825 \cdot\left(S_{\text {палуб }}\right)^{0,0758}$, для существенных модернизаций и конверсий $-S_{c l}=0,0867 \cdot\left(S_{\text {палvб }}\right)^{0,1573}$.

При модернизации или конверсии РКПС наблюдается увеличение количества экипажа и обслуживающего персонала на одного пассажира, что также является нормой при повышении уровня обслуживания.

Среднее соотношение $\overline{n_{\text {эк }}} / \overline{n_{\text {nac }}}$ для базовых проектов составляет 0,24, для проектов с сохранением философии (незначительная модернизация) работы РКПС - 0,38. Для существенных модернизаций $\overline{n_{\text {эк }}} / \overline{n_{\text {nac }}}=0,51$, что вполне соответствует современным представлениям о круизах. 
Заключение. Выполнен детальный анализ распределения площадей на базовых проектах РКПС, а также на модернизированных и конверсионных судах.

Работы по модернизации и конверсии на таких судах проводятся, в первую очередь, для повышения комфортабельности круизов. Учитывая, зачастую, невозможность изменения габаритных размерений на РКПС, единственным возможным вариантом остается уменьшение пассажировместимости.

При этом происходит перераспределение площадей по сравнению с базовыми проектами: увеличивается удельная площадь кают с 2,0-4,5 м²/чел. до 9,0-12,0 м²/чел., удельная площадь общественных помещений с 4,5-9,0 м²/чел. до 11,5-16,0 м²/чел.

Увеличивается также количество экипажа и обслуживающего персонала на одного пассажира до 0,51 , что повышает уровень обслуживания на борту.

Зависимости, полученные при выполнении работы, позволят упростить процесс проектирования на начальных стадиях проектирования, в том числе, при выполнении проектных работ по модернизации и конверсии РКПС.

\section{СПИСОК ЛІТЕРАТУРИ}

1. Егоров А.Г. Речные круизные пассажирские суда: инновачионные решения и их применимость при конверсии // Вестник ОНМУ. Oдесса: ОНМУ, 2018. Bыn.4 (57). C. 23-52.

2. Егоров Г.В., Егоров А.Г. Исследование надежности и риска эксплуатачии отечественных речных круизных пассажирских судов // Науч.- техн. сб. Российского Морского Регистра Судоходства. Bып. 38/39. СПб, 2015. С. 22-35.

3. Егоров А.Г. Отечественные круизные пассажирские суда: состояние и прогноз // Материалы Хмежд. научно-техн. конф. «Инноваиии в судостроении и океанотехнике». Нико-лаев: НУК, 2019. C. 104-106.

4. Cruise Industry News: 2020 European River Cruise Market. Special report. Edited by Oivind Mathisen. New York, September, 2019. $114 \mathrm{p}$.

5. Market Observation for inland navigation in Europe. Annual report 2019. Edited by the Secretariat of the Central Commission for Navigation on the Rhine. Strasbourg, September, 2019. 176 p.

6. Payne S.M. Designing Passenger Ships [Электронный ресурс] // Keynote lecture of the Intern. Conf. "Design \& Operation of Passenger Ships». London (UK): Royal Institution of Naval Architects, 2019 (презентаиия в формате ppt, 68 слайдов).

7. Lloyd Werft in major NCL fleet lengthening programme // Shiprepair \& Conversion Technology. London (UK): Royal Institute of Naval Architects, 2nd Quarter 1998. P. 22-24. 
ВІСНИК

ОДЕСЬКОГО НАЦІОНАЛЬНОГО

МОРСЬКОГО УНІВЕРСИТЕТУ

№ 1 (61), 2020
HERALD

OF THE ODESSA NATIONAL

MARITIME UNIVERSITY

8. Cruise Ship Repairs and Refits (Feature 3) // Shiprepair \& Maintenance. London (UK): Royal Institute of Naval Architects, 1st Quarter 2019. P. 28-35.

9. Егоров Г.В., Егоров А.Г. Анализ закономерностей списания речных круизных судов и прогноз состава речного флота с определением наиболее востребованных типов судов для конверсии и модернизачии // Морской Вестник. 2019. № 1 (69). С. 21-27.

10. Сайт компании "Thurgau Travel» [Электронный ресурс]. URL: https://www.thurgautravel.ch/ (дата обращения 22.11.2019).

11. Сайт компании «Мостурфлот» [Электронный ресурс]. URL: https://www.mosturflot.ru/post?id=29188 (дата обращения 22.11.2019).

\section{REFERENCES}

1. Egorov A.G. (2018). Rechnye kruiznye passazhirskie suda: innovacionnye resheniya $i$ ikh primenimost pri konversii [River cruise passenger ships: innovative solutions and their applicability in conversion works]. Visnuk ONMU (Reporter of Odessa National Maritime University), 4 (57), 23-52 [in Russian].

2. Egorov G.V., Egorov A.G. (2015). Issledovanie nadezhnosti i riska ekspluatacii otechestvennykh rechnykh kruiznykh passazhirskikh sudov [Research of reliability and risk operation of native river cruise passenger ships]. Nauch.-tekhn. sb. Rossijskogo Morskogo Registra Sudohodstva (Sc-Tech. Collection book of Russian Maritime Register of Shipping), 38/39, 22-35 [in Russian].

3. Egorov A.G. (2019). Otechestvennye kruiznye passazhirskie suda: sostoyanie i prognoz [Native cruise passenger ships: condition and prognosis]. Materialy X mezhdun. nauchno-tekhn. konf. «Innova-tsii v sudostroenii i okeanotekhnike» (Proceedings of X international ScTech. conference «Innovations in shipbuilding and ocean technique»). Nikolayev, 104-106 [in Russian].

4. Mathisen O. (2019). Cruise Industry News: 2020 European River Cruise Market. Special report. New York, 114 p.

5. Secretariat of the Central Commission for Navigation on the Rhine (2019). Market Observation for inland navigation in Europe. Annual report. Strasbourg, $176 \mathrm{p}$.

6. Payne S.M. (2019). Designing Passenger Ships // Keynote lecture of the Intern. Conf. «Design \& Operation of Passenger Ships». London, Royal Institution of Naval Architects, 68 slides (ppt format presentation).

7. (1998). Lloyd Werft in major NCL fleet lengthening programme // Shiprepair \& Conversion Technology. London (UK): Royal Institute of Naval Architects, 22-24.

8. (2019). Cruise Ship Repairs and Refits (Feature 3) // Shiprepair \& Maintenance. London (UK): Royal Institute of Naval Architects, 2835 . 
ВІСНИК

ОДЕСЬКОГО НАЦІОНАЛЬНОГО

МОРСЬКОГО УНІВЕРСИТЕТУ

№ 1 (61), 2020
HERALD

OF THE ODESSA NATIONAL

MARITIME UNIVERSITY

№ 1 (61), 2020

9. Egorov G.V., Egorov A.G. (2019). Analiz zakonomernostej spisa-niya rechnykh kruiznykh sudov $i$ prognoz sostava rechnogo flota $s$ opredeleniem naibolee vostrebovannykh tipov sudov dlya konversii $i$ modernizacii [Analysis of trends of decommissioning of river cruise vessels and prognosis of structure of river fleet with definition of most demanded types of vessels for conversion and modernization]. Morskoy Vestnik (Maritime Reporter), 1 (69), 21-27 [in Russian].

10. "Thurgau Travel» cruise company website. Retrieved from: https:// www.thurgautravel.ch/ (access date 22.11.2019).

11. "Mosturflot» cruise company website. Retrieved from: https:// www.mosturflot.ru/post?id=29188 (access date 22.11.2019).

Стаття надійшла до редакиії 24.01.20

Посилання на статтю: Егоров А.Г. Влияние работ по переоборудованию круизных пассажирских судов на формирование помещений для пассажиров и экипажа // Вісник Одеського національного морського університету: Зб. наук. праць, 2020. № 1(61). C. 29-54. DOI 10.47049/2226-1893-2020-1-29-54.

Article received 24.01.2020

Reference a JournalArtic: Yegorov, A. (2020). Influence of modernization works of cruise passenger ships on formation of compartments for passengers and crew. 1(61), 29-54 // Herald of the Odessa national maritime university. DOI 10.47049/2226-1893-2020-1-29-54. 